\title{
Lesser Antillean snake faunas: distribution, ecology, and conservation concerns
}

Robert W. Henderson

\begin{abstract}
Thirty-three islands in the Lesser Antilles range in area from 0.06 to1,510 $\mathrm{km}^{2}$ and harbour 25 species of snakes representing five families and 10 genera. The islands have suffered at least six, and possibly as many as 11 , historical extirpations and at least one historical extinction. The number of snake species per island is $1-5$, and species richness is correlated with island size and habitat diversity. Islands that harbour three or more species exhibit greater habitat diversity, are larger, have a higher maximum elevation, and are situated closer to the South American mainland, the source area for most genera. North of the Guadeloupe Archipelago, islands support one or two species (an Alsophis or an Alsophis and a Typhlops). From the Guadeloupe Archipelago southwards, snake faunas have species belonging to genera that are widespread on the Neotropical mainland:
\end{abstract}

Boa, Corallus, Chironius, Clelia, Liophis, Mastigodryas and Bothrops. Between 50 and $75 \%$ of the Lesser Antillean snake fauna preys on Anolis lizards. Snake faunas in the Lesser Antilles are not saturated, and many islands could support additional species; fossil evidence and written records indicate that they did. The islands have a 5,000year history of habitat alteration, but introduced predators probably have had the greatest negative impact on snakes. The potential establishment of an alien snake (e.g. Elaphe guttata) into the Lesser Antilles is a valid concern. Preventing additional introductions of alien predators and protecting satellite island populations of threatened species are the two most important mechanisms for snake conservation in the region.

Keywords Alien predators, biogeography, island populations, Lesser Antilles, snakes, West Indies.

\section{Introduction}

The West Indies are considered a biodiversity hotspot based on a concentration of endemic species and loss of habitat (Myers et al., 2000). Focusing only on the herpetofauna, $99 \%$ of West Indian frogs are endemic, and endemicity is $93 \%$ among reptiles (Hedges, 2001). Within the Lesser Antilles (Fig. 1), $87.5 \%$ of the snake species are endemic and some are among the rarest in the world (e.g. Alsophis antiguae, Liophis cursor and L. ornatus). Many other snakes have small ranges, rendering them susceptible to extirpation or extinction. The Greater Antilles, despite a richer snake fauna, have suffered two historical extinctions (Alsophis ater on Jamaica and A. melanichnus on Hispaniola) and no extirpations. The Lesser Antillean snake fauna has suffered at least six, and possibly as many as 11 , extirpations and at least one, and possibly as many as four, extinctions.

Here I review the composition of Lesser Antillean snake faunas from the perspectives of distribution, diet,

Robert W. Henderson Section of Vertebrate Zoology, Milwaukee Public Museum, 800 W. Wells Street, Milwaukee, WI 53233-1478, USA. E-mail rh@mpm.edu

Received 23 June 2003. Revision requested 4 September 2003. Accepted 24 November 2003. habitat diversity and source area. Snakes and humans have a shared history of about 5,000 years in the region and late Holocene activity by humans has probably altered patterns of distribution and diversity throughout the West Indies, 'rendering unreliable the data traditionally used in ecological and biogeographic studies that consider only the historically known fauna' (Steadman et al., 1984). Pre-human history has also had a profound influence on regional biodiversity (e.g. Ricklefs \& Bermingham, 2001) and, although the analysis that follows is based largely on ecological time, I also review situations in evolutionary time.

\section{Methods}

Previously published data provided much of the information for this analysis, most notably those by Schwartz \& Henderson (1991), Hedges (1996) and Ricklefs \& Lovette (1999). However, I have conducted fieldwork on all of the major islands in the Lesser Antilles with the exception of Barbados, and I have visited most of the snake-harbouring satellite islands as well. I used habitat diversity indices calculated by Ricklefs \& Lovette (1999), based on the five habitat types recognized in vegetation maps produced by Stehle (1945). In most cases diets are based on previously published data. Distances from 


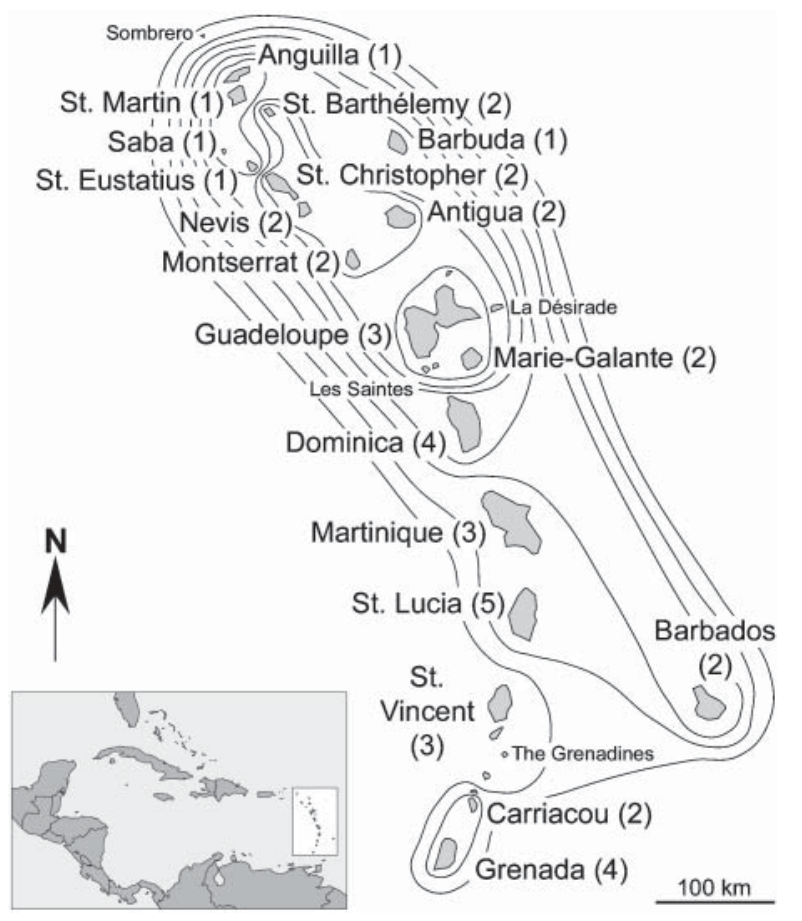

Fig. 1 Map of the Lesser Antilles incorporating the results of a cluster analysis. The numbers in parentheses indicate the number of snake species that occur (or occurred) on an island. Islands outlined in a smaller area have more similar snake faunas than islands outlined in a broader area. For example, Guadeloupe and Marie-Galante are more similar than are Guadeloupe and Dominica, or Guadeloupe and Montserrat. St. Vincent is the only island that harbours a snake species belonging to a genus (Chironius) not found on any other island in the Lesser Antilles.

South America to individual islands are from Lescure (1987).

I omitted introduced frogs and reptiles from the summary tables, although they are possibly important to the ecology of Lesser Antillean snakes today. For example, Eleutherodactylus johnstonei is established on many islands outside its native range and it is probably an important food source for Alsophis, Liophis and Mastigodryas. On Grenada E. euphronides is the only native Eleutherodactylus. Its altitudinal range is 300$840 \mathrm{~m}$ and its distribution covers only $16 \mathrm{~km}^{2}$ (Hedges, 1999), but E. johnstonei is virtually ubiquitous (Germano et al., 2003) and almost any frog that Mastigodryas bruesi eats is probably E. johnstonei. Anguilla was until recently devoid of any anurans but now E. johnstonei and Osteopilus septentrionalis are established. The diet of Alsophis rijgersmaei on Anguilla was restricted to lizards but frogs are now included in its diet. Breuil (2002) documented Alsophis rijgersmaei feeding on introduced $O$. septentrionalis on St Barthélemy. Two snakes, M. bruesi on Barbados (Underwood et al., 1999), and the parthenogenetic typhlopid Ramphotyphlops braminus on Anguilla, St Martin and St Barthélemy (Breuil, 2002; Hodge et al.,
2003) were introduced by humans and are not included in the analysis that follows.

Although Guadeloupe is sometimes considered two separate islands (Basse-Terre and Grande-Terre), I have opted to view it as one. Reference to an island means that island only; e.g. reference to Martinique does not include its satellite Rocher de Diamant. A single record of Leptotyphlops tenellus has been recorded for Antigua, but it is probably an error; I have not included it in this analysis. All statistical analyses were carried out using SYSTAT 10.2 (Systat Software, Inc., Point Richmond, USA). Pearson correlations used log transformed data for island areas and elevations. For the hierarchical cluster analysis incorporated into Fig. 1, all data were first standardized. For all tests, $\alpha=0.05$.

\section{Results}

\section{Islands and distribution}

Thirty-three islands ranging in area from 0.06 to $1,510 \mathrm{~km}^{2}$ support snake populations (Table 1 ). The smallest island with a snake population is Rocher de Diamant, a satellite of Martinique, and the largest island devoid of snakes is La Désirade $\left(22 \mathrm{~km}^{2}\right)$ in the Guadeloupe Archipelago. Species of Alsophis occur on 16 islands on eight island banks (i.e. islands on a given submarine bank that were united at an earlier time of lower sea levels) from Anguilla to Dominica. Liophis occurs on nine islands and five banks. Arboreal boids in Corallus occur on 11 islands and two banks. Typhlops has the greatest latitudinal distribution, occurring on 10 islands and eight banks from Anguilla in the north to Grenada in the south.

\section{Snake species diversity}

Twenty-five snake species from 10 genera and five families occur on Lesser Antillean islands, with 0-5 species per island (Table 2). Colubrids (5 genera, 13 species) and typhlopids (1 genus, 6 species) have more representatives than other families (represented by 1-2 genera and 1-3 species) (Table 2). Typhlops is represented by six species, Alsophis by five and Liophis by four. No genus is represented by more than one species per island. Snake species diversity is correlated with island area $(n=19$ islands, $r=0.683, \mathrm{P}=0.008)$ and the habitat diversity index $(r=0.729, \mathrm{P}=0.004)$.

Cluster analysis based on genera occurring on each island indicates a close relationship between the more northern islands that harbour only Alsophis or Alsophis and Typhlops. Similarly, islands that support three or more species show strong affinities. The centrally located Guadeloupe, Marie-Galante and Dominica that harbour 
Table 1 Lesser Antillean snakes ordered by family, with their primary habit, maximum snout-vent length (SVL), diet and IUCN Red List Status (IUCN, 2003).

\begin{tabular}{|c|c|c|c|}
\hline Species (habit) ${ }^{1}$ & Maximum SVL (mm) & Diet & Red List category ${ }^{2}$ \\
\hline \multicolumn{4}{|l|}{ Leptotyphlopidae } \\
\hline Leptotyphlops bilineatus (F) & 108 & ants, termites & \\
\hline \multicolumn{4}{|l|}{ Typhlopidae $^{3}$} \\
\hline Typhlops annae $(\mathrm{F})$ & 110 & ants, termites & \\
\hline Typhlops dominicanus $(\mathrm{F})$ & 385 & ants, termites & \\
\hline Typhlops geotomus $(\mathrm{F})$ & 213 & ants, termites & \\
\hline Typhlops guadeloupensis $(\mathrm{F})$ & 284 & ants, termites & \\
\hline Typhlops monastus (F) & 258 & ants, termites & \\
\hline Typhlops tasymicris (F) & 181 & ants, termites & \\
\hline \multicolumn{4}{|l|}{ Boidae } \\
\hline Boa constrictor $(\mathrm{T})$ & c. 3,000 & rodents, opossums & \\
\hline Corallus cookii (A) & 1,374 & Anolis, rodents & \\
\hline Corallus grenadensis $(\mathrm{A})$ & 1,625 & Anolis, rodents & \\
\hline \multicolumn{4}{|l|}{ Colubridae } \\
\hline Alsophis antiguae $(\mathrm{T})$ & 1,023 & Anolis, Ameiva, Sphaerodactylus & $\mathrm{CR}$ \\
\hline Alsophis antillensis $(\mathrm{T})$ & 930 & Eleutherodactylus, Anolis & \\
\hline Alsophis rijgersmaei $(\mathrm{T})$ & 790 & Anolis & EN \\
\hline Alsophis rufiventris (T) & 920 & Eleutherodactylus, Anolis & EN \\
\hline Alsophis sanctonum $(\mathrm{T})$ & $670+$ & Eleutherodactylus, Anolis & \\
\hline Chironius vincenti $(\mathrm{T})$ & 1,260 & Eleutherodactylus & $\mathrm{CR}$ \\
\hline Clelia clelia $(\mathrm{T})$ & c. 2,000 & lizards, snakes, rodents & \\
\hline Clelia errabunda $(\mathrm{T})$ & 1,380 & ?snakes, ?lizards, ?rodents & \\
\hline Liophis cursor $(\mathrm{T})$ & 671 & Eleutherodactylus, Anolis & $\mathrm{CR}$ \\
\hline Liophis juliae $(\mathrm{T})$ & 627 & Eleutherodactylus, Anolis & \\
\hline Liophis ornatus $(\mathrm{T})$ & $?$ & ?Anolis & EN \\
\hline Liophis perfuscus $(\mathrm{T})$ & 797 & ?Anolis & EN \\
\hline Mastigodryas bruesi $(\mathrm{T}, \mathrm{A})$ & 830 & Eleutherodactylus, Anolis & \\
\hline \multicolumn{4}{|l|}{ Viperidae } \\
\hline Bothrops caribbaea $(\mathrm{T})$ & c. 1,300 & rodents, opossums & \\
\hline Bothrops lanceolata $(\mathrm{T})$ & 1,580 & rodents, ?opossums & \\
\hline
\end{tabular}

${ }^{1}$ Primary microhabitat: A, arboreal; $\mathrm{F}$, fossorial; $\mathrm{T}$, terrestrial.

${ }^{2} \mathrm{CR}$, Critically Endangered; EN, Endangered.

${ }^{3}$ Rather than snout-vent length, total length is provided for species of Typhlops.

the northern Alsophis and the southern Liophis, are somewhat transitional (Fig. 1). St Vincent is the only island that harbours a genus (Chironius) not represented on another island.

\section{Origin}

Hedges (1996) considered South America the source area of all Lesser Antillean snakes except Typhlops (from Africa) and Leptotyphlops bilineatus (from North and/or South America), and dispersal the mechanism explaining their presence in the West Indies. Twenty-three of the 25 species $(92.0 \%)$ are endemic to the Lesser Antilles (the exceptions are Boa constrictor and Clelia clelia), 15 (60.0\%) are endemic to a single island bank, and $10(40.0 \%)$ are endemic to a single island.

The mean distance from the South American mainland of one and two species islands is $808 \pm 253 \mathrm{~km}$ (range $=360-1,035 \mathrm{~km}$; if Barbados and the Grenada satellite Carriacou are omitted, the nearest island would be Marie-Galante at $700 \mathrm{~km}$ ) and is significantly greater than that of islands with more than two snake species (459 $\pm 205 \mathrm{~km}$; 175-725 km, Mann-Whitney U Test, $1 \mathrm{df}$, $\mathrm{P}=0.011$.

Alsophis probably entered the region from the north (e.g. the Puerto Rico Bank). Typhlops may have invaded from the north (e.g. T. geotomus) and from the South American mainland (T. tasymicris) (Thomas, 1989). Members of all other genera presumably emigrated from the south.

\section{Habitat diversity}

The mean habitat diversity index for major islands harboring one or two snake species $(1.53 \pm 0.72, \mathrm{n}=13)$ is significantly less than for islands sustaining three or more extant species ( $3.20 \pm 0.31, \mathrm{n}=6$; Mann-Whitney $\mathrm{U}, 1 \mathrm{df}, \mathrm{P}<0.001)$, as are the mean number of vegetation 
Table 2 Snake species occurring on each island known to harbour snake populations (listed approximately from north to south; see Fig. 1), with area, maximum elevation and, where available, habitat diversity index (HD) and area of vegetation zones, of the 19 major Lesser Antillean islands (data from Ricklefs \& Lovette, 1999).

\begin{tabular}{|c|c|c|c|c|c|c|c|c|}
\hline \multirow{2}{*}{$\begin{array}{l}\text { Island and } \\
\text { species }^{1}\end{array}$} & \multirow{2}{*}{$\begin{array}{l}\text { Area } \\
\left(\mathrm{km}^{2}\right)\end{array}$} & \multirow{2}{*}{$\begin{array}{l}\text { Maximum } \\
\text { elevation }(\mathrm{m})^{2}\end{array}$} & \multirow[b]{2}{*}{ HD } & \multicolumn{5}{|c|}{ Area of vegetation zones $\left(\mathrm{km}^{2}\right)$} \\
\hline & & & & Mangrove & Xerophytic & Mesophytic & Hygrophytic & Montane \\
\hline $\begin{array}{l}\text { Anguilla }(0,2) \\
\text { Alsophis rijgersmaei }\end{array}$ & 90 & 60 & 1.00 & 0 & 90 & 0 & 0 & 0 \\
\hline $\begin{array}{l}\text { Scrub }(0,1) \\
\text { Alsophis rijgersmaei }\end{array}$ & 4.5 & 79 & & & & & & \\
\hline $\begin{array}{l}\text { St. Martin }(1,2) \\
\text { Alsophis rijgersmaei }\end{array}$ & 85 & 392 & 1.22 & 0 & 77 & 9 & 0 & 0 \\
\hline $\begin{array}{l}\text { St. Barthélemy }(1,1) \\
\text { Typhlops annae } \\
\text { Alsophis rijgersmaei }\end{array}$ & 22 & 424 & 1.00 & 0 & 22 & 0 & 0 & 0 \\
\hline $\begin{array}{l}\text { Saba }(1,1) \\
\text { Alsophis rufiventris }\end{array}$ & 13 & 870 & 1.80 & 0 & 9 & 3 & 1 & 0 \\
\hline $\begin{array}{l}\text { St. Eustatius }(1,2) \\
\text { Alsophis rufiventris }\end{array}$ & 20 & 600 & 1.22 & 0 & 18 & 2 & 0 & 0 \\
\hline $\begin{array}{l}\text { St. Christopher }(1,2) \\
\text { Alsophis rufiventris } \\
\text { Typhlops geotomus }\end{array}$ & 170 & 1,156 & 2.90 & 7 & 83 & 51 & 16 & 14 \\
\hline $\begin{array}{l}\text { Nevis }(1,2) \\
\text { Alsophis rufiventris }^{3} \\
\text { Typhlops geotomus }\end{array}$ & 130 & 985 & 2.70 & 0 & 61 & 43 & 26 & 0 \\
\hline $\begin{array}{l}\text { Antigua }(1,2) \\
\text { Alsophis antiguae } \\
\text { Typhlops geotomus }\end{array}$ & 280 & 402 & 1.14 & 0 & 261 & 19 & 0 & 0 \\
\hline $\begin{array}{l}\text { Great Bird }(0,2) \\
\text { Alsophis antiguae } \\
\text { Typhlops geotomus }\end{array}$ & 0.09 & 30 & & & & & & \\
\hline $\begin{array}{l}\text { Barbuda }(1,2) \\
\text { Typhlops geotomus }\end{array}$ & 160 & 62 & 1.00 & 0 & 160 & 0 & 0 & 0 \\
\hline $\begin{array}{l}\text { Montserrat }(1,1) \\
\text { Typhlops monastus } \\
\text { Alsophis antillensis }\end{array}$ & 100 & 914 & 2.61 & 0 & 49 & 34 & 17 & 0 \\
\hline $\begin{array}{l}\text { Guadeloupe }(3,1) \\
\text { Typhlops guadeloupensis } \\
\text { Alsophis antillensis }{ }^{4} \\
\text { Liophis juliae }\end{array}$ & 1,510 & 1467 & 3.73 & 210 & 576 & 314 & 367 & 44 \\
\hline $\begin{array}{l}\text { Terre-de-Haut }(1,1) \\
\text { Alsophis sanctonum } \\
\text { Liophis juliae }\end{array}$ & 4.5 & 309 & & & & & & \\
\hline $\begin{array}{l}\text { Terre-de-Bas }(1,1) \\
\text { Alsophis sanctonum }\end{array}$ & 9.5 & 293 & & & & & & \\
\hline $\begin{array}{l}\text { Marie-Galante }(1,1) \\
\text { Alsophis antillensis }{ }^{3} \\
\text { Liophis juliae }\end{array}$ & 160 & 204 & 1.12 & 5 & 150 & 4 & 0 & 0 \\
\hline $\begin{array}{l}\text { Dominica }(2,1) \\
\text { Typhlops dominicanus } \\
\text { Boa constrictor } \\
\text { Alsophis antillensis } \\
\text { Liophis juliae }\end{array}$ & 751 & 1,447 & 2.79 & 0 & 72 & 286 & 334 & 60 \\
\hline $\begin{array}{l}\text { Martinique }(1,1) \\
\text { Leptotyphlops bilineatus } \\
\text { Liophis cursor } \\
\text { Bothrops lanceolatus }\end{array}$ & 1,100 & 1,397 & 3.08 & 19 & 405 & 417 & 234 & 25 \\
\hline
\end{tabular}


Table 2 Continued

\begin{tabular}{|c|c|c|c|c|c|c|c|c|}
\hline \multirow{2}{*}{$\begin{array}{l}\text { Island and } \\
\text { species }^{2}\end{array}$} & \multirow{2}{*}{$\begin{array}{l}\text { Area } \\
\left(\mathrm{km}^{2}\right)\end{array}$} & \multirow{2}{*}{$\begin{array}{l}\text { Maximum } \\
\text { elevation }(\mathrm{m})^{2}\end{array}$} & \multirow[b]{2}{*}{ HD } & \multicolumn{5}{|c|}{ Area of vegetation zones $\left(\mathrm{km}^{2}\right)$} \\
\hline & & & & Mangrove & Xerophytic & Mesophytic & Hygrophytic & Montane \\
\hline $\begin{array}{l}\text { R. de Diamant }(0,1) \\
\text { Liophis cursor }\end{array}$ & 0.06 & 176 & & & & & & \\
\hline $\begin{array}{l}\text { St. Lucia }(0,2) \\
\text { Leptotyphlops bilineatus } \\
\text { Boa constrictor } \\
\text { Clelia errabunda } \\
\text { Liophis ornatus }{ }^{3} \\
\text { Bothrops caribbaeus }\end{array}$ & 616 & 950 & 3.08 & 0 & 254 & 206 & 122 & 33 \\
\hline $\begin{array}{l}\text { Maria Major }(0,1) \\
\text { Liophis ornatus }^{4}\end{array}$ & 0.09 & 90 & & & & & & \\
\hline $\begin{array}{l}\text { Barbados }(0,1) \\
\text { Leptotyphlops bilineatus } \\
\text { Liophis perfuscus }{ }^{6}\end{array}$ & 430 & 340 & 1.22 & 10 & 388 & 32 & 0 & 0 \\
\hline $\begin{array}{l}\text { St. Vincent }(1,2) \\
\text { Corallus cookii } \\
\text { Chironius vincenti } \\
\text { Mastigodryas bruesi }\end{array}$ & 350 & 1,234 & 3.27 & 0 & 125 & 114 & 91 & 19 \\
\hline $\begin{array}{l}\text { Bequia }(0,2) \\
\text { Corallus grenadensis } \\
\text { Mastigodryas bruesi }\end{array}$ & 18 & 262 & & & & & & \\
\hline $\begin{array}{l}\text { Baliceaux }(0,1) \\
\text { Corallus grenadensis } \\
\text { Mastigodryas bruesi }\end{array}$ & 1 & 183 & & & & & & \\
\hline $\begin{array}{l}\text { Ile à Quatre }(0,1) \\
\text { Corallus grenadensis } \\
\text { Mastigodryas bruesi }\end{array}$ & 2 & 104 & & & & & & \\
\hline $\begin{array}{l}\text { Mustique }(0,1) \\
\text { Corallus grenadensis } \\
\text { Mastigodryas bruesi }\end{array}$ & 5.2 & 152 & & & & & & \\
\hline $\begin{array}{l}\text { Canouan }(0,1) \\
\text { Corallus grenadensis }\end{array}$ & 7.4 & 247 & & & & & & \\
\hline $\begin{array}{l}\text { Mayreau }(0,1) \\
\text { Corallus grenadensis }\end{array}$ & 2.6 & 61 & & & & & & \\
\hline $\begin{array}{l}\text { Union }(0,1) \\
\text { Corallus grenadensis } \\
\text { Mastigodryas bruesi }\end{array}$ & 8.1 & 305 & & & & & & \\
\hline $\begin{array}{l}\text { Petite Martinique }(0,1) \\
\text { Corallus grenadensis }\end{array}$ & 0.7 & 226 & & & & & & \\
\hline $\begin{array}{l}\text { Carriacou }(0,2) \\
\text { Corallus grenadensis } \\
\text { Mastigodryas bruesi }\end{array}$ & 34 & 294 & 1.00 & 0 & 34 & 0 & 0 & 0 \\
\hline $\begin{array}{l}\text { Grenada }(1,2) \\
\text { Typhlops tasymicris } \\
\text { Corallus grenadensis } \\
\text { Clelia clelia } \\
\text { Mastigodryas bruesi }\end{array}$ & 310 & 840 & 3.26 & 4 & 126 & 89 & 74 & 17 \\
\hline
\end{tabular}

${ }^{1}$ Numbers in parentheses following island names refer to the number of native species of Eleutherodactylus and Anolis, respectively, on that island.

${ }^{2}$ Some elevations presented by Ricklefs \& Lovette (1999) were obviously wrong. The elevations used here are from Hedges (1999).

${ }^{3}$ Extirpated.

${ }^{4}$ If not extirpated, on the verge of being so; if extirpated, Liophis cursor and L. ornatus are extinct.

${ }^{5}$ Extinct.

${ }^{6}$ Probably extinct. 
zones $(1-2$ species islands $=2.3 \pm 1.18,1-5$; islands with $>2$ species $=4.5 \pm 0.55,4-5$; Mann-Whitney U, $1 \mathrm{df}, \mathrm{P}<0.002$ ) and (based only on the 19 islands used by Ricklefs \& Lovette, 1999) mean size (1-2 species islands $=130.3 \pm 118.0 \mathrm{~km}^{2}$; islands with 3 species or more $=772.8 \pm 462.3 \mathrm{~km}^{2} ; \mathrm{P}<0.001$ ). If all one- and two-snake islands are included, the mean is only $65.1 \mathrm{~km}^{2}$. Besides species richness, the habitat diversity index for the 19 islands was correlated with island area $(r=0.606, \mathrm{P}=0.046)$ and maximum elevation $(r=0.797$, $\mathrm{P}=0.0001)$.

\section{Macrohabitat}

Eight of 25 (32.0\%) Lesser Antillean snakes are fossorial (Leptotyphlops bilineatus and Typhlops spp.), two (Corallus spp.) are arboreal (8.0\%), and the remaining $15(60.0 \%)$ are terrestrial or largely terrestrial (Table 2). Mastigodryas bruesi has been encountered sleeping in trees, and I have seen it active in trees and on the ground. The arboreal Corallus spp. and semi-arboreal M. bruesi occur only on the St Vincent and Grenada banks. Strictly arboreal colubrids and species with strong aquatic habits are absent from Lesser Antillean snake communities.

\section{Diet}

Ten species (all colubrids) prey predominantly on lizards and/or frogs. Two species (Corallus cookii and C. grenadensis) exhibit an ontogenetic shift in diet from anoles to rodents, three species (Boa constrictor, Bothrops caribbaeus and B. lanceolatus) feed primarily on rodents. Clelia spp. presumably feed/fed primarily on squamate reptiles (Murphy, 1997; Boos, 2001). Leptotyphlops and Typhlops are ant and termite eaters (Table 2).

Although lizard and frog predators occur throughout the region, Dominica is the northernmost island that harbors a species (Boa constrictor) that preys predominantly on mammals, and only St Lucia and Grenada support two or more species that prey on mammals. On St Lucia, both species are common and are largely sympatric (Lazell, 1964). On Grenada Clelia clelia is rare or extirpated; Corallus grenadensis is widespread and common. Of satellite islands, only Canouan and Mayreau (Grenada Bank) lack a species with a frog and lizard diet; they do, however, harbour an anole and rodent predator. However, the absence of the former may reflect insufficient collecting. St Vincent harbors two frog eaters. Both are uncommon, and one (Chironius) may be restricted to elevations of 275-600 m (Henderson \& Haas, 1993). The other generally occurs at lower elevations, and preys more often on lizards than anurans (Schwartz \& Henderson, 1991).

Colubrids that prey on earthworms and other invertebrates or fishes are missing from the Lesser
Antillean snake fauna. Both are widespread and relatively common on Trinidad and the adjacent mainland.

\section{Prey species diversity and population densities}

The West Indies support the highest densities of lizards encountered anywhere in the world. Lesser Antillean islands harbour one or two species of Anolis, and population densities of 2,000 ha-1 are not unusual, and some may approach 10,000 ha ${ }^{-1}$ (Roughgarden, 1995). The large teiid Ameiva fuscata has been recorded at $379 \mathrm{ha}^{-1}$ on Dominica (Bullock \& Evans, 1990). Diminutive gekkos of the genus Sphaerodactylus also occur in great numbers: S. fantasticus has been recorded at 7,900 ha $\mathrm{h}^{-1}$ on Grand Ilet des Saintes (Breuil, 2002), S. parous at $>50,000 \mathrm{ha}^{-1}$ on Anguilla (Nava et al., 2001) and S. vincenti may reach $8,200 \mathrm{ha}^{-1}$ on Martinique (Leclair \& Provencher, 1988). Although comparable data for anurans are lacking, some species of Eleutherodactylus are virtually ubiquitous (e.g. E. johnstonei on Grenada; Germano et al., 2003) and attain high densities (Ovaska, 1991).

\section{Discussion}

Islands, distribution, snake species diversity and origin

The Lesser Antilles contain no endemic snake genera, and each genus represented has congenerics on the Neotropical mainland. Faunal compositions on islands north of Guadeloupe are simple, regardless of whether these islands are low outer arc islands composed of marine sediments and with elevations $<600 \mathrm{~m}$, or more physiographically complex, volcanic inner arc islands with elevations $>600 \mathrm{~m}$. Faunas comprise either a single species (Alsophis) or two species (Alsophis and Typhlops). Alsophis spp. are ground-dwelling frog and lizard predators; Typhlops spp. are fossorial and consume ants and termites.

From the Guadeloupe Archipelago southwards, snake faunas have additional species in genera that are widespread on the Neotropical mainland: Boa, Corallus, Chironius, Clelia, Liophis, Mastigodryas and Bothrops. Guadeloupe and Marie-Galante are centrally located and Guadeloupe is a composite, with a volcanic portion to the west and an uplifted portion to the east. Its snake fauna includes a representative of the northern Alsophis and the southern Liophis, as do other islands in the Guadeloupe Archipelago (Marie-Galante) and Dominica. Both Alsophis and Liophis are now rare on Guadeloupe. On Dominica, Alsophis and Liophis are widespread, but they may be ecologically segregated. Dominica also harbors Boa constrictor.

Lesser Antillean snake faunas are probably not saturated. A xeric habitat-adapted, arboreal, Anolis-eating species such as Oxybelis aeneus would probably be 
successful on many of the islands. However, O. aeneus may not be a good candidate for over-water colonization. Its slender, elongate morphology and low body mass may render it especially susceptible to dehydration. Similarly, aquatic species such as Helicops angulatus may not be good colonizers, and Lesser Antillean islands do not offer much suitable habitat (ponds, streams, rivers), or suitable trophic resources (freshwater fishes, tadpoles) (Ford \& Ford, 2002). Colubrid invertebrate predators are absent from the West Indies; the exclusion of, for example, a species of Atractus or Ninia is predictable.

Some islands that have non-volant mammalian faunas comprised entirely of introduced species (Mus musculus, Rattus rattus and possibly Herpestes javanicus) supported native mammals during the late Pleistocene and Holocene. Pregill et al. (1994) indicated that most or all faunal losses in the Lesser Antilles are related to prehistoric and/or historic human activity. For example, Antigua may have supported Boa constrictor and a rice rat (Oryzomyini sp.); Boa constrictor no longer occurs on the island and the rat is extinct (Table 3). Boas may have disappeared from Antigua because the rat, possibly its primary food source, was eliminated by human activity before the arrival of Europeans and the introduction of Mus and Rattus.

St Christopher probably could support another snake species (e.g. Boa constrictor), but there is no evidence of a mammal-eating snake ever being part of the island's fauna. Montserrat at one time harboured up to four species of rice rats (Pregill et al., 1994), but we can probably assume that no predominantly mammal-eating snake ever became established there. Successful colonization of an island depends on several factors, including (1) surviving a long over-water journey, (2) finding appropriate habitat and food, and (3) reproducing. The 'missing' mammal-eater may have failed to overcome factor 1 , but even that is insignificant if factors 2 and 3 are missing. Many individuals of a species have probably made landfalls, but failed to survive or reproduce.

The disappearance of Clelia from the Lesser Antilles is intriguing. Underwood (1995) attributed the extinction of C. errabunda on St Lucia to human activity. Breuil (2003) believed that Clelia sp. had a shared history with humans on Guadeloupe; Clelia does not now occur there, but one specimen purportedly from that island exists, as does fossil evidence (S. Grouard in Breuil, 2002) (Table 3). On Grenada, C. clelia is, at best, rare. My field work there spans 15 years, and I have never seen one. Clelia is a large snake ( $>2.0 \mathrm{~m}$ snout-vent length) and seems out of place in the Lesser Antilles where colubrids rarely exceed $1.0 \mathrm{~m}$. Clelia clelia is a heavy-bodied, ground-dwelling, trophic generalist (although lizards and snakes probably constitute a large proportion of its diet). Despite its size, it may have been as susceptible to mongoose predation as smaller Alsophis and Liophis. Alternatively, Clelia populations may, for a variety of reasons (climate, habitat degradation), have been on a downward trajectory for many hundreds of years.

\section{Habitat diversity}

Ricklefs \& Lovette (1999) found that amphibian and reptile richness was strongly correlated with habitat diversity and weakly correlated with island area. I found snake species richness significantly correlated with island size and habitat diversity. Larger islands generally have greater habitat diversity, which is strongly correlated with elevation. Thus, large physiographically and ecologically complex islands are more likely to support more species than smaller, less complex islands. Larger, more complex islands also lie closer to South America, thereby increasing the likelihood of colonization.

Northern islands with low habitat diversity indices support representatives of the same two snake genera as islands with high habitat diversity indices, and satellite islands of $c .1 .0 \mathrm{~km}^{2}$ support as many snake species as associated islands hundreds of times greater in area. Several two-species islands (St Christopher, Nevis, Montserrat) have habitat diversity indices approaching or surpassing that of Dominica, an island that supports four species, but Dominica is 4.4 to 7.5 times larger and 200-300 km closer to the mainland.

Table 3 Island records of Lesser Antillean snake species known only from fossil evidence or written historical records.

\begin{tabular}{lll}
\hline Island & Species & Source \\
\hline Antigua & Boa constrictor & Steadman et al., 1984; Pregill et al., 1994 \\
Barbuda & Boidae & Steadman et al., 1984; Pregill et al., 1994 \\
& Alsophis ?antillensis & Pregill et al., 1994 \\
Guadeloupe & Clelia cf. C. clelia & Auffenberg, 1958; Pregill et al., 1994 \\
& Boa constrictor & Breuil, 2002 \\
Martinique & Clelia sp. & Breuil, 2002, 2003 \\
\hline
\end{tabular}




\section{Macrohabitat, diet, prey species diversity and population densities}

Frogs and lizards accounted for $95.7 \%$ of all prey items in West Indian colubrids (Henderson \& Crother, 1989). Anoles comprised $56.8 \%$ of the total, and among lizard genera, Anolis accounted for $75.8 \%$ of the prey. Boids and Greater Antillean tropidophiids also prey frequently on anoles. Anoles and other lizards occur at very high densities and are ubiquitous on many islands. Consequently, that $50-75 \%$ of Lesser Antillean snakes feed on anoles at some time during their lives is not surprising. Frogs are often similarly abundant. Abundant food, along with a snake fauna that is not saturated with species, probably contribute to the high densities at which some snake species occur on some islands (Henderson, 2001, 2002, 2003).

\section{Conservation}

The Lesser Antilles were first peopled c. 5,000 years ago (Rouse, 1989) and agricultural exploitation probably began on, for example, Grenada, at least 2,000 years ago (Bullen, 1964, 1965). This is ample time to affect the biota on small islands. However, Fosberg (1983) noted that the impact of Europeans made that of indigenous peoples seem minor, but regardless the loss of species since the arrival of humans is evident (Pregill et al., 1994). However, the shared history of humans and snakes probably does not entirely explain the current composition of snake faunas. Evidence of climate change in the circumCaribbean (Curtis et al., 2001) during that same shared history may have profoundly affected intra-island snake distribution, and perhaps the survival of certain species. Ricklefs \& Bermingham (2001) suggested a scenario of mass extinction or accelerated colonization for the Lesser Antillean avifauna 0.55 to 0.75 million years ago. Snakes undoubtedly were similarly affected.

The snake fauna of the Lesser Antilles is at a vulnerable stage in its history. Although largely via circumstantial evidence (Henderson, 1992; but see Wilson, 2003), the introduction of the mongoose Herpestes javanicus probably remains the single greatest threat to snake populations in the Lesser Antilles. Species of Alsophis and Liophis are diurnal, largely ground-dwelling, and usually $<1.0 \mathrm{~m}$ snout-vent length. On mongoose-free islands (e.g. Saba, Montserrat, Dominica) Alsophis and Liophis occur in a variety of altered habitats, often in proximity to human activity (including homes), and their populations are healthy. Extirpations (e.g. Antigua, St Christopher) or extinctions (Barbados?) of these snakes have occurred only on those islands that support mongoose populations (Sajdak \& Henderson, 1991).

In general, snakes in the Lesser Antilles appear versatile, occur in a variety of habitats (including urban and suburban situations), and are tolerant of dramatic alterations to their environments (Henderson \& Powell, 2001; Henderson, 2002). The only snake species that may be severely habitat restricted is Chironius vincenti; it occurs in primary and secondary rainforest on St Vincent (Henderson \& Haas, 1993). Nevertheless, the West Indies as a whole retains just over $10 \%$ of its original forest cover (Myers et al., 2000) and any development that includes clear-cutting of forest may have a negative impact on wildlife. However, as the economies on many of the islands shift from agriculture to service industries, land previously devoted to farming is reverting to forest in some areas.

Alien species of frogs and lizards are being introduced with accelerating frequency, and now snakes, too, are reaching islands where they do not belong. Underwood et al. (1999) recently reported the occurrence of Mastigodryas bruesi on Barbados. They determined that these snakes probably originated from St Vincent, that they arrived on Barbados due to human activity (possibly with banana shipments), and that the species is established on Barbados and has been there for 2030 years. The impact, if any, of Ramphotyphlops braminus on several islands in the region remains to be determined. Perhaps most discouraging is the discovery of the colubrid snake Elaphe guttata, native to the eastern US, on Anguilla (Hodge et al., 2003), St Barthélemy (Breuil, 2002), and Antigua (Powell \& Henderson, 2003). These are currently considered waifs or stowaways, but if the species is being unknowingly transported (probably with decorative plants from Florida), the establishment of breeding populations on one or more islands is a real possibility.

The composition and structure of snake communities on islands of the Lesser Antilles remain in flux, with the number of species on a given island waxing and waning. Although human-mediated introductions of snake species are not desirable, should a breeding population of Elaphe guttata become established on Anguilla, St Barthélemy, or Antigua (each of which harbours Alsophis or Alsophis + Typhlops), we will have the opportunity to observe whether a mammal-eating, semi-arboreal second or third species survives and, if it does, how it affects the structure of the existing snake fauna.

Concern for the conservation of snake populations in the Lesser Antilles should rival that exhibited for birds and mammals, or any animal group. Despite the versatility of some species, small geographic ranges, habitat alteration, and introduced predators render these highly endemic reptiles susceptible to future extirpations and extinctions. The establishment of nature reserves, education, legislation, and research are important steps to prevent further losses. Equally important, however, is that mongooses, cats, and rats are not introduced to additional islands in the area (either intentionally or 
accidentally), and that satellite island populations of threatened snake species (e.g. Alsophis antiguae on Great Bird Island) be given highest conservation priorities by their island nations.

\section{Acknowledgements}

I am grateful to Michel Breuil, Blair Hedges, James Lazell, three anonymous reviewers and, especially, Robert Powell for constructive comments on earlier versions of this paper. Recent fieldwork in the Lesser Antilles has been funded by the Windway Foundation.

\section{References}

Auffenberg, W. (1958) A small fossil herpetofauna from Barbuda, Leeward Islands, with the description of a new species of Hyla. Quarterly Journal of the Florida Academy of Science, 21, 248-254.

Boos, H.E.A. (2001) The Snakes of Trinidad \& Tobago. Texas A\&M University Press, College Station, USA.

Breuil, M. (2002) Histoire naturelle des Amphibiens et Reptiles terrestres de l'archipel Guadeloupéen. Guadeloupe, Saint-Martin, Saint-Barthélemy. Publications Scientifiques du Muséum national d' Histoire naturelle, Patrimoines Naturels 54, Paris, France

Breuil. M. (2003) In the footsteps of French naturalists, a "battle" of iguanas, and "improvements" in biodiversity. In Islands and the Sea: Essays on Herpetological Exploration in the West Indies (eds R.W. Henderson \& R. Powell), pp. 255-270. Contributions in Herpetology 20. Society for the Study of Amphibians and Reptiles, Ithaca, USA.

Bullen, R.P. (1964) The archaeology of Grenada, West Indies. Contributions, Florida State Museum, Social Sciences, 11, 1-67.

Bullen, R.P. (1965) Archaeological chronology of Grenada. American Antiquity, 31, 237-241.

Bullock, D.J. \& Evans, P.G.H. (1990) The distribution, density and biomass of terrestrial reptiles in Dominica, West Indies. Journal of Zoology, London, 222, 421-443.

Curtis, J.H., Brenner, M. \& Hodell, D.A. (2001) Climate change in the circum-Caribbean (late Pleistocene to Present) and implications for regional biogeography. In Biogeography of the West Indies: Patterns and Perspectives (eds C.A. Woods \& F.E. Sergile), pp. 35-54. CRC Press, Boca Raton, USA.

Ford, N.B. \& Ford, D.F. (2002) Notes on the ecology of the South American water snake Helicops angulatus (Squamata: Colubridae) in Nariva Swamp, Trinidad. Caribbean Journal of Science, 38, 129-132.

Fosberg, F.R. (1983) The human factor in the biogeography of oceanic islands. Compte Rendu des sciences de la Société de biogéographie, 59, 147-190.

Germano, J.M., Sander, J.M., Henderson, R.W. \& Powell, R. (2003) Herpetofaunal communities in Grenada: a comparison of altered sites, with an annotated checklist of Grenadian amphibians and reptiles. Caribbean Journal of Science, 39, 68-76.

Hedges, S.B. (1996) The origin of West Indian amphibians and reptiles. In Contributions to West Indian Herpetology: A Tribute to Albert Schwartz (eds R. Powell \& R.W. Henderson), pp. 95-128. Contributions in Herpetology 2. Society for the Study of Amphibians and Reptiles, Ithaca, USA.
Hedges, S.B. (1999) Distribution patterns of amphibians in the West Indies. In Patterns of Distribution of Amphibians: A Global Perspective (ed. W.E. Duellman), pp. 211-254. John Hopkins University Press, Baltimore, USA.

Hedges, S.B. (2001) Biogeography of the West Indies: an overview. In Biogeography of the West Indies: Patterns and Perspectives (eds C.A. Woods \& F.E. Sergile), pp. 15-33. CRC Press, Boca Raton, USA.

Henderson, R.W. (1992) Consequences of predator introductions and habitat destruction on amphibians and reptiles in the post-Columbus West Indies. Caribbean Journal of Science, 28, 1-10.

Henderson, R.W. (2001) Islands that rake the air \& sea. Fauna, 2, 14-27.

Henderson, R.W. (2002) Neotropical Treeboas: Natural History of the Corallus hortulanus Complex. Krieger Publishing Company, Malabar, USA.

Henderson, R.W. (2003) Night shift. In Islands and the Sea: Essays on Herpetological Exploration in the West Indies (eds R.W. Henderson \& R. Powell), pp. 271-278. Contributions in Herpetology 20. Society for the Study of Amphibians and Reptiles, Ithaca, USA

Henderson, R.W. \& Crother, B.I. (1989) Biogeographic patterns of predation in West Indian colubrid snakes. In Biogeography of the West Indies: Past, Present, and Future (ed. C.A. Woods), pp. 479-517. Sandhill Crane Press, Gainesville, USA.

Henderson, R.W. \& Haas, G.T. (1993) Status of the West Indian snake Chironius vincenti. Oryx, 27, 181-184.

Henderson, R.W. \& Powell, R. (2001) Responses by the West Indian herpetofauna to human-influenced resources. Caribbean Journal of Science, 37, 41-54.

Hodge, K.V.D., Censky, E.J. \& Powell, R. (2003) The Reptiles and Amphibians of Anguilla, British West Indies. Anguilla National Trust, The Valley, Anguilla.

IUCN (2003) 2003 IUCN Red List of Threatened Species. IUCN, Gland, Switzerland [http://www.redlist.org, accessed 28 April 2004].

Lazell, J.D., Jr. (1964) The Lesser Antillean representatives of Bothrops and Constrictor. Bulletin of the Museum of Comparative Zoology, 132, 245-273.

Lazell, J.D., Jr. (1967) Wiederentdeckung von zwei angeblich ausgestorbenen Schlangenarten der westinischen Inseln. Salamandra, 3, 91-97.

Leclair, R. \& Provencher, G. (1988) Demographic traits of a small sphaerodactyline lizard from Martinique, West Indies. In Program and Abstracts of the Herpetologists' League, Society for the Study of Amphibians and Reptiles, and the American Society of Ichthyologists and Herpetologists, Annual Meeting, The University of Michigan, Ann Arbor, pp. 127-128.

Lescure, J. (1987) Le peuplement en reptiles et amphibiens des Petites Antilles. Bulletin de la Société zoologique de France, 112, 327-342.

Murphy, J.C. (1997) Amphibians and Reptiles of Trinidad and Tobago. Krieger Publishing Company, Malabar, USA.

Myers, N., Mittermeier, R.A., Mittermeier, C.G., da Fonseca, G.A.B. \& Kent, J. (2000) Biodiversity hotspots for conservation priorities. Nature, 403, 853-858.

Nava, S.S., Lindsay, C.R., Henderson, R.W. \& Powell, R. (2001) Microhabitat, activity, and density of a dwarf gecko (Sphaerodactylus parvus) on Anguilla, West Indies. Amphibia-Reptilia, 22, 455-464.

Ovaska, K. (1991) Reproductive phenology, population structure, and habitat use of the frog Eleutherodactylus johnstonei in Barbados, West Indies. Journal of Herpetology, 25, 424-430. 
Powell, R. \& Henderson, R.W. (2003) A second set of addenda to the checklist of West Indian amphibians and reptiles. Herpetological Review, 34, 341-345

Pregill, G.K., Steadman, D.W. \& Watters, D.R. (1994) Late Quaternary vertebrate faunas of the Lesser Antilles: historical components of Caribbean biogeography. Bulletin of the Carnegie Museum of Natural History, 30, 1-51.

Ricklefs, R.E. \& Bermingham, E. (2001) Nonequilibrium diversity dynamics of the Lesser Antillean avifauna. Science, 294, 1522-1524.

Ricklefs, R.E. \& Lovette, I.J. (1999) The roles of island area per se and habitat diversity in the species-area relationships of four Lesser Antillean faunal groups. Journal of Animal Ecology, 68, $1142-1160$

Roughgarden, J. (1995) Anolis Lizards of the Caribbean: Ecology, Evolution, and Plate Tectonics. Oxford University Press, New York, USA.

Rouse, I. (1989) Peopling and repeopling of the West Indies In Biogeography of the West Indies: Past, Present, and Future (ed. C.A. Woods), pp. 119-136. Sandhill Crane Press, Gainseville, USA.

Sajdak, R. \& Henderson, R.W. (1991) Status of West Indian racers in the Lesser Antilles. Oryx, 25, 33-38.

Schwartz, A. \& Henderson, R.W. (1991) Amphibians and Reptiles of the West Indies: Descriptions, Distributions, and Natural History. University of Florida Press, Gainesville, USA.

Steadman, D.W., Pregill, G.K. \& Olson, S.L. (1984) Fossil vertebrates from Antigua, Lesser Antilles: evidence for late Holocene human-caused extinctions in the West Indies. Proceedings of the National Academy of Science, 81, 4448-4451.

Stehle, H. (1945) Los tipos forestales de las islas del Caribe. Caribbean Forester, 6 (Suppl.), 273-408.
Thomas, R. (1989) The relationships of Antillean Typhlops (Serpentes: Typhlopidae) and the description of three new Hispaniolan species. In Biogeography of the West Indies: Past, Present, and Future (ed. C.A. Woods), pp. 409-432. Sandhill Crane Press, Gainesville, USA.

Underwood, G. (1995) A Tale of Old Serpents. St Lucia National Trust, St Lucia.

Underwood, G., Horrocks, J.A. \& Daltry, J.C. (1999) A new snake from Barbados. Journal of the Barbados Museum and Historical Society, 45, 67-75.

Wilson, B. (2003) Of mongooses and lizards. In Islands and the Sea: Essays on Herpetological Exploration in the West Indies (eds R.W. Henderson \& R. Powell), pp. 113-119. Contributions in Herpetology 20. Society for the Study of Amphibians and Reptiles, Ithaca, USA.

\section{Biographical sketch}

Robert W. Henderson is curator of herpetology at the Milwaukee Public Museum, Milwaukee, Wisconsin. For the past 25 years his research has focused on West Indian reptiles, especially snakes. For about 15 years he has concentrated on Neotropical treeboas (Corallus), with emphasis on West Indian populations. Occasional sojourns take him to the Neotropical mainland and Trinidad, usually in search of additional treeboa data. 